\title{
Effects of Prunus spinosa $L$. fruits on experimental wound healing
}

\section{Prunus spinosa L. meyvelerinin deneysel yara iyileşmesi üzerine etkileri}

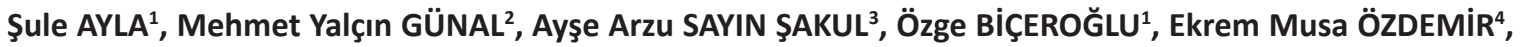 \\ Mehmet Evren OKUR ${ }^{5}$, Derya Çiçek POLAT ${ }^{6}$, Neslihan ÜSTÜNDAĞ OKUR7 ${ }^{7}$, Bülent Emre BíLGiç8
}

\begin{abstract}
We investigated the wound healing efficacy of the methanol extracts of Prunus spinosa L. fruits using an excisional cutaneous wound model in mice. We used 32 C57/Black mice equally divided into four groups. Group 1 Control, Group 2 vehicle (glycerine), Group 3 Prunus spinosa L., Group 4 Madecassol. Prunus spinosa L.and Madecassol were applied for 10 days by creating a excisional wound model on the back of each mouse in each group. At the end of the 10th day, samples from wound areas were taken for histologic follow-up, scoring with hematoxylineosin and immunohistochemical (TGF- $b$, COL1A1) staining. Wound healing was evaluated and scored by newly formed collagen structure, increase in TGF $b$ and epidermal and dermal regeneration, granulation tissue thickness, angiogenesis (new vessel formation). Prunus spinosa L. increased wound healing rates by promoting granulation tissue, epidermal regeneration and angiogenesis. In addition there was a significant increase in collagen and TGF [beta] ratios in immunohistochemical staining. At the end of the 4 and 10 days after treatment, a significant increase was observed in wound contraction and re-epithelialization in both Prunus spinosa and madecassol treated groups compared to the control and vehicle groups. Our findings support the beneficial effects of Prunus spinosa for augmenting wound healing. The anti-inflammatory, antioxidant and antibacterial activities of Prunus spinosa by way of increasing collagen synthesis and decreasing the number of inflammatory cells during wound healing have suggested that it may be useful for treating skin wounds.
\end{abstract}

Keywords: Wound healing, Prunus spinosa L., antioxidant öz

Farelerde oluşturduğumuz deneysel yara modellerinde, Prunus Spinosa L. metanollü meyve ekstresini kullanarak, bu ekstrenin yara iyileşmesindeki etkisini araştırdık. Otuz iki adet C57/Black fare ile 4 deney grubu oluşturuldu. Birinci grup kontrol grubu, 2. grup taşıyıcı (gliserin) grup, 3. grup Prunus spinosa, 4. grup madecassol grubu idi ve her bir grupta farelerin sırtında eksizyonel yara modeli oluşturularak Prunus Spinosa L. ve madecassol 10. gün boyunca uygulandı. Onuncu gün sonunda yara bölgeleri histolojik takip için alındı, yara dokuları hematoksilen-eosin ve immunohistokimyasal (TGF- $\beta$, COL1A1) boyalarla boyanarak, yara iyileşmesi için epidermal ve dermal rejenerasyon, granülasyon doku oluşumu, anjiogenezis (yeni damar oluşumu), immunohistokimyasal boyalarla yeni oluşan kollajen yapılanması ve TGF $\beta$ artışı değerlendirilerek skorlandı. Prunus spinosa L'nin yara dokusunda iyileşme oranlarını, granülasyon dokusunu, epidermal rejenerasyonu ve anjiogenezisi artırarak gösterdiği yine immünohistokimyasal boyamalarda kollajen ve TGF $\beta$ oranlarında istatistiksel olarak anlamlı bir artışın olduğu gözlendi. Yine 4. günün ve 10. günün sonunda yara kontraksiyonunda ve yara yerinin reepitelizasyonunda ilaç ve madecassol grubunda kontrol grubuna kıyasla anlamlı bir artış gözlenmiştir. Bulgularımız, Prunus spinosa L'nin yara iyileşmesini desteklediğini göstermiştir. Prunus spinosanın antiinflamatuvar, antioksidan ve antibakteriyel etkisi ile, kollajen sentezini artırarak ve inflamatuvar hücre sayısını azaltarak yara iyileşmesinin tedavisinde kullanılabileceğini düşündürdü.

Anahtar kelimeler: Yara iyileşmesi, Prunus spinosa L., antioksidan

Received: 17.07 .2017

Accepted: 29.08.2017

${ }^{1}$ Department of Histology and Embryology, School of Medicine, Istanbul Medipol University, Regenerative and Restorative Medicine Research Center, Remer, Istanbul, Turkey

${ }^{2}$ Department of Physiology, School of Medicine, Alanya Alaaddin Keykubat University, Alanya, Turkey

${ }^{3}$ Department of Pharmacology, School of Medicine, Istanbul Medipol University, Regenerative and Restorative Medicine Research Center, Remer, Istanbul, Turkey

${ }^{4}$ Department of Animal Facility, Istanbul Medipol University, Istanbul, Turkey

${ }^{5}$ Department of Pharmacology, Faculty of Pharmacy, Anadolu University, Eskişehir, Turkey

${ }^{6}$ Department of Pharmaceutical Botanic, Faculty of Pharmacy, Ankara University, Ankara, Turkey

${ }^{7}$ Department of Pharmaceutical Technology, Faculty of Pharmacy, Istanbul Medipol University, Istanbul, Turkey

${ }^{8}$ In Vitro Fertilization Unit, Zeynep Kamil Maternity And Children Hospital, Istanbul, Turkey

Yazışma adresi: Şule Ayla, Department of Histology and Embryology, School of Medicine, Istanbul Medipol University, Regenerative and Restorative Medicine Research Center, Remer, Istanbul, Turkey

e-mail: sayla@medipol.edu.tr 


\section{Giriş}

Prunus spinosa L. (P. spinosa) (çakal eriği), Rosaceae familyasına ait Avrupa, Batı Asya, Kuzeybatı Afrika ve Anadolu'da doğal olarak bulunan bir erik türü olmakla birlikte ${ }^{1-3}, 3-4 \mathrm{~m}$. uzunluğunda, dikenli ve yabani olarak yetişen çalı formunda bir bitkidir ${ }^{1,3-5}$.

Ülkemizde yaprakları kabız için, çiçekleri diüretik ve kurt düşürücü, meyveleri ise müshil olarak kullanılır . Ayrıca bazı bölgelerde taze/kurutulmuş meyveleri; vücuda direnç kazandırdığı, kan yapıcı etkisi ve romatizmal ağrılarda yarar sağladığı için hoşaf şeklinde de tüketilmektedir ${ }^{6}$.

Meyveleri, yukarıda belirtilen etkilerine ek olarak geleneksel olarak kanama durdurucu, diüretik, bağırsak fonksiyonlarını arttırıcı olarak kullanılırken ${ }^{4,5,7}$, meyve suları antienflamatuvar etkisi nedeniyle ağız ve farenks mukozasında garagara şeklinde kullanılmaktadır. Meyvelerinden elde edilen şurupların pürgatif ya da diüretik olduğu da saptanmıştır ${ }^{8}$.

P. spinosanın meyveleri; tokoferoller ( $\alpha$-tokoferol, $\beta$-tokoferol, $\gamma$-tokoferol, $\delta$-tokoferol), askorbik asit ve $\beta$-karoten gibi maddelerin yanında polyfenolik bileşikler ve flavonoitler (kersetin, rutin, hiperosit) içermektedir ${ }^{6,9}$. Bununla beraber, çakal eriği meyvelerinde; bir flavonoit çeşidi olan ve kardiyovasküler koruyucu, antibakteriyal ve antioksidan etkileri olan çeşitli antosiyaninler (siyanidin-3-rutinosit, peonidin3-rutinozit, siyanidin-3-glikozit) bulunmaktadır ${ }^{10}$. P. spinosa meyvelerinin antioksidan etkinlikleri çeşitli çalışmalarda gösterilmiştir ${ }^{4,7,9,11}$.

Yara iyileşmesi, hücre-hücre ve hücre-matrix etkileşimi ile inflamasyon, hücre proliferasyonu ve yeniden şekillenme süreçlerini içeren bir yapılanmadır. Yara iyileşme sürecine katkıda bulunabilecek birçok geleneksel bitkilerle çalışmalar devam etmektedir ${ }^{12-}$ ${ }^{15}$. Biz de bu çalışmamızla farelerde $P$. spinosa meyvelerinin yara iyileşmesi üzerine etkilerini araştırmayı amaçladık.

\section{GEREÇ ve YÖNTEM}

\section{Bitki materyali}

\section{Metanol ekstresinin hazırlanması}

P. spinosa meyveleri, 15 Ekim 2016 tarihinde Ahlatlıbel, Ankara'da toplanmıştır. Meyvelerin çekirdekleri çıkarıldıktan sonra püre haline getirilmiştir. Püre haline getirilmiş olan numune manyetik karıştırıcı (Heidolph MR3001) metanol (Sigma-Aldrich) yardımı ile ekstre edilmiştir (200 g numune, $400 \mathrm{ml}$ x 3 gün). Süzgeç kağıdı yardımıyla süzülmüştür. Elde edilen metanol ekstresi rotary evaporator (Heidolph WB2000) yardımıyla distillenmiştir.

\section{Kimyasallar}

Ekstrenin hazırlanmasında metanol (Sigma-Aldrich, Almanya) ve hayvanlara uygulanmak için gliserin (Doğa ilaç, Türkiye) kullanılmıştır. P. spinosa meyvelerinden hazırlanmış olan metanol ekstresinden 20 mg. tartılıp, 10 mL gliserin/distile su karışımı (50:50) içerisinde $15 \mathrm{dk}$. süre ile karıştırılarak hayvanlara uygulanacak formülasyonlar hazırlanmıştır.

\section{Deney hayvanları ve deney grupları}

Çalışmamız İstanbul Medipol Üniversitesi Hayvan Deneyleri Yerel Etik Kurulu tarafından onaylanmıştır. Tüm deneyler "Avrupa Topluluğu Rehberi"nin (European Community Guidelines) uygun gördüğü uluslararası uygulamalar esas alınarak yapılmıştır.

\section{Deney grupları}

Çalışmada, 32 adet 3-4 aylık erkek C57/Black fare ile eşit sayıda 4 deney grubu oluşturuldu. Hayvanlar havalandırma koşulları ve nem oranı uygun, ortam sıcaklığı $24^{\circ} \mathrm{C}$ olan İstanbul Medipol Üniversitesinde Hayvan Deneyleri Laboratuvarında bekletildi. Hayvanlar istedikleri kadar standart yem ve su ile beslendiler. Gece-gündüz döngüsü 12 'şer saat olarak ayarlandı. 
1. grup (Kontrol grubu) (n:8): Ayçiçek yağı uygulanan grup (yara iyileşmesinde etkinliği olmadığı bilinen referans molekül).

2. grup (Taşıyıcı grubu) (n:8): Gliserin uygulanan grup.

3. grup (P. spinosa $L$ ) (n:8): Prunus spinosa L. ekstresi (Gliserinle sulandırılmış) uygulanan grup.

4. grup (Referans ilaç grubu) (n:8): Madecassol krem uygulanan grup.

\section{Yara modeli}

Genel anesteziden (80-100 mg/kg xylazine ve $10 \mathrm{mg} /$ kg ketamin intraperitoneal (i.p.) enjeksiyon sonrası farelerin sırt kılları tıraş edildi ve povidon iyot çözeltisi ile yıkandı. Tüm işlemler aseptik olarak gerçekleştirildi. İki adet eksizyonel deri yarası, orta hattan $1 \mathrm{~cm}$ ve $5 \mathrm{~mm}$ çaplı bir punch biyopsi aleti kullanılarak tam kat deri yaraları oluşturuldu ${ }^{16}$. Tüm uygulamalar, fareler 10. günde sakrifiye edilinceye kadar günlük olarak, yaraların yüzeyini tamamen kaplayacak şekilde topikal uygulandı.

\section{Makroskopik yara iyileşmesi değerlendirmesi}

Fotoğraflar, Canon dijital 160 kamera (Canon Inc., Tokyo, Japonya) kullanılarak, her yaranın 0, 2, 4, 6, 8 ve $10^{\prime}$ uncu günlerde yara kontraksiyonları ölçülerek resimlendi. Fotoğraflar yaraya $90^{\circ}$ açı ile çekildi. Yara yüzey alanları, iyileşme esnasındaki değişiklikler görüntü analizeri kullanılarak ölçümlendi (Image J.2.0 software, National Institutes of Health, Bethesda, $\mathrm{MD}$ ) ve yara dokusu yüzey ölçümü (YDYÖ) iyileşme oranları hesaplandı.

\section{Histoloji ve immünohistokimya}

Onuncu günün sonunda, hayvanlar dekapitasyon yöntemi kullanılarak sakrifiye edildi. Yara dokusu etrafında yaklaşık $3 \mathrm{~mm}$ boşluk bırakılacak şekilde çıkarıldı. Çıkarılan dokular, ışık mikroskobu incelemeleri için \%10'luk formol çözeltisi içerisine konuldu. \%10'luk formol solüsyonu içerisinde 24-48 saat süresince bekletilen dokulara rutin parafin takibi yapıldı. Parafin bloklardan hazırlanan (Mikrotom (Thermo
Microm HM 340E) $5 \mu$ m'lik kesitlere HematoksilenEozin (HE) ve immunohistokimya (COL1A1 (3G3): sc-293182 (Santa Cruz Biotechnology, TGF $\beta 1$ (500M66):sc-65378 (Santa Cruz Biotechnology) boyaları uygulandı ve Nikon Eclipse Ni araştırma mikroskobu ile görüntülenme yapıldı.

Histopatolojik skorlama kör olarak gerçekleştirildi ve birden çok lezyonun aynı farede olması durumunda skorların ortalaması alındı. Histopatolojik skorlama daha önce gerçekleştirilmiş olan çalışmalarda kullanılan Galeano ve ark. ${ }^{17}$ metodu ile yapıldı. Yara bölgesi dermis ve epidermis rejenerasyonu, neovaskülarizasyon, granülasyon dokusunun oluşumu ve kalınlığı açısından değerlendirildi. Epidermal ve dermal rejenerasyon için: 1 , çok az epidermal organizasyon $\geq$ dokunun \%20, 2, Az (incomplete) epidermal organizasyon $\geq$ dokunun $\% 40$, 3, orta epidermal organizasyon $\geq$ dokunun $\% 60,4$, Tam (complete) epidermal organizasyon $\geq$ dokunun \%80'i. Granülasyon doku artışı için 1, İnce granülasyon dokusu, 2, orta granülasyon dokusu, 3, kalın granülasyon dokusu, 4, daha kalın granülasyon dokusu. Anjiogenezis için 1, zayıf anjiogenezis (alanda 1 ya da 2 kapiller damar), yüksek derecede ödem ve hemoraji, konjesyon, 2, Yeni şekillenen az sayıda kapiller damar ( 3 ya da 4 adet), orta ödem ve hemoraji, konjesyon, 3, Yeni şekillenen orta sayıda kapiller damar ( 5 ya da 6 adet), orta ödem ve hemoraji, konjesyon, 4, Yeni şekillenen ve iyi yapılı çok sayıda kapiller damar (7'den fazla) çok az ödem.

\section{İmmunohistokimyasal skorlama}

TGF $\beta$ ve antikollajen tip I immunoreaktiviteleri semikantitatif yöntem ile değerlendirildi. Her deneğe ait preparattan rastgele seçilen 5'er farklı alanda değerlendirme yapıldı ve ortalamaları alındı. Skorlamada 0: Boyama yok, 1: Az boyama 2: Orta şiddette boyama 3: Şiddetli boyama olacak şekilde değerlendirildi ${ }^{18}$.

\section{İstatistiksel değerlendirmeler}

Tüm istatistiksel analizler SPSS 18.0 yazılım programı kullanılarak değerlendirildi. Tüm datalar ortalama değer \pm S.D. olarak belirtildi. Makroskobik yara iyileş- 
mesi farklı gruplar arasında one way ANOVA ile analiz edildi. Histopatolojik verilerin değerlendirilmesinde ise gruplar arasında Kruskal-Wallis varyans analiz testi kullanıldı. $p<0,05$ olan değerler istatistiksel olarak anlamlı kabul edildi.

\section{BULGULAR}

\section{Makroskopik yara iyileşmesi}

P. Spinosa ve madecassol uygulanmış deney gruplarında 2., 4. ve 10. günde, kontrol grubuna oranla YDYÖ iyileşme oranlarında belirgin bir artış gözlendi $p<0.05$ (Şekil 1). Yine deney gruplarında yara kontraktilitesi ve epitelizasyon iyileşme periyotları kontrol ve taşıyıcı gruba göre daha kısa süre olarak gözlendi (Şekil 2).

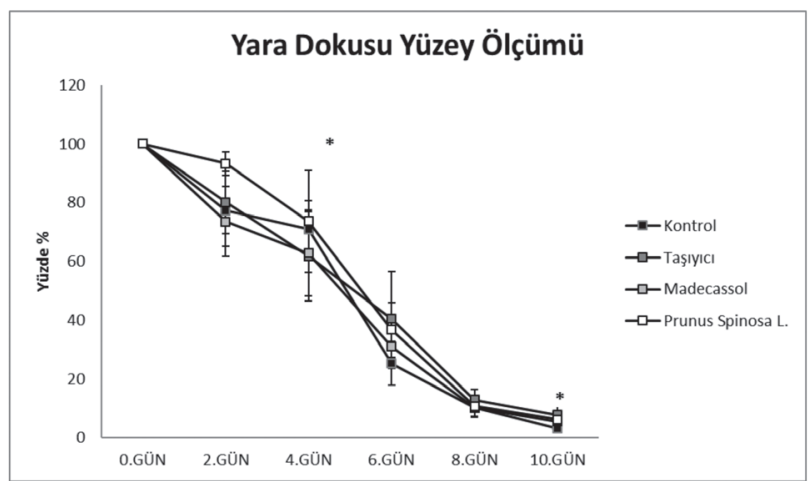

Figür 1. Yara dokusu yüzey ölçümü (YDYÖ) iyileşme oranları $(p<0,05)$.

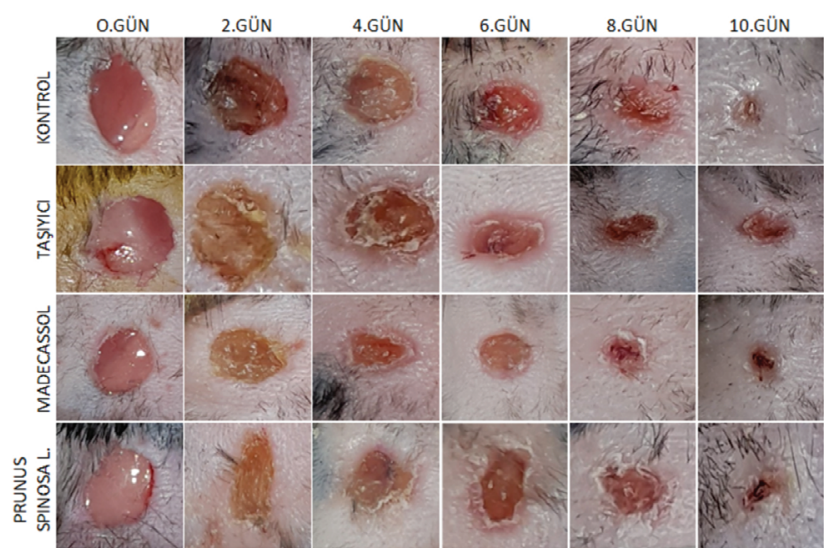

Figür 2. Başlangıç yaralarından sonra her bir grubun 0., 2., 4., 6., 8. ve 10. günlere göre yara iyileşmesine ait örnekleri.

\section{Yara iyileşmesinin histolojisi}

HE kesitlerden epidermal ve dermal rejenerasyon, granülasyon dokusunun kalınlığı, anjiogenesiz ayrı ayrı değerlendirildi ve skorlandı (Şekil 3). Kontrol ve gliserin grubunda az epidermal ve dermal rejenerasyon, orta kalınlıkta granülasyon dokusu, her alanda 1 yada 2 damar yapısı gözlendi, madecassol grubunda komplet epidermal ve dermal rejenerasyon, kalın granülasyon dokusu, her alanda 7'den fazla damar yapısı gözlenirken, $P$. spinosa $L$. grubunda komplet epidermal ve dermal rejenerasyon, orta granülasyon dokusu, her alanda 5 ya da 6 damar yapısı gözlendi (Şekil 3). Yapılan histopatolojik skorlamada P. spinosa L. grubunun epidermal ve dermal rejenerasyon oranı, granülasyon doku kalınlığı ve anjiogenezis oranı madecassol grubu kadar iyi olmasa da, kontrol grubuna oranla anlamlı derecede $(p<0,05)$ yüksekti (Şekil 4$)$.

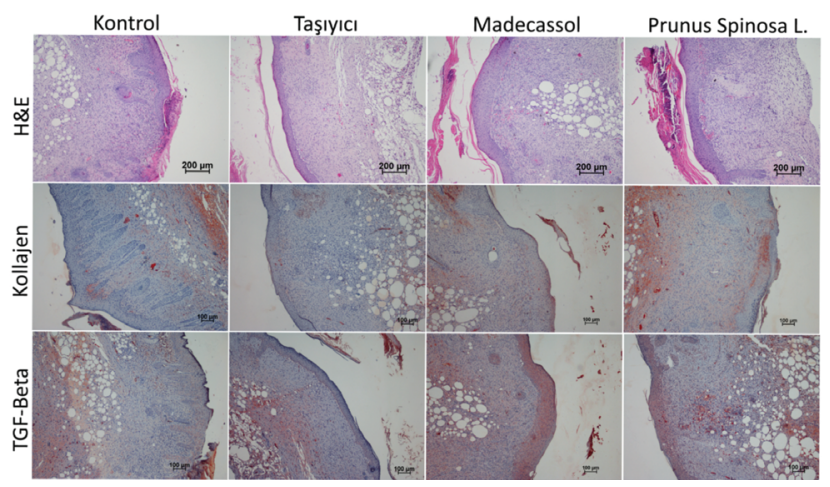

Figür 3. Yaraların ışık mikroskobu görüntüleri (Hemotoksilen \& Eosin (H\&E) X100 ve immünohistokimya (TGF $\beta$ ve kollajen (COL1A1)X100.

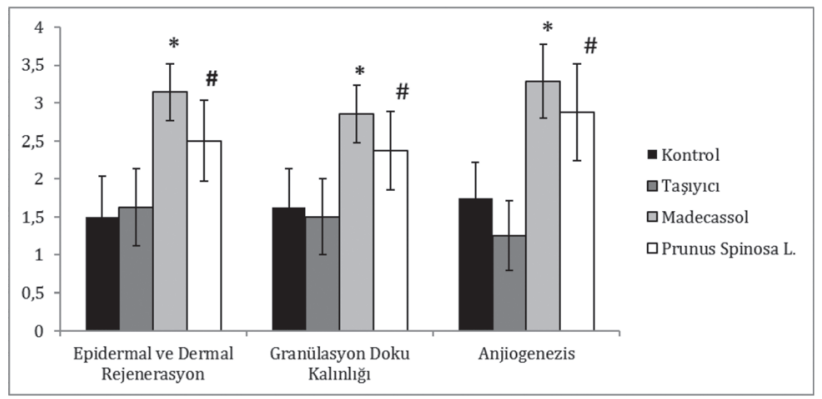

Figür 4. Gruplar arasında histolojik (H\&E) yara iyileşme skorlaması $(p<0,05)$.

İmmunohistokimya boyamalarında, kontrol ve taşıyıCI grubun TGF $\beta$ ve kollajen boyamalarına ait prepa- 
ratlarda çok az boyanma gözlenirken, kontrol grubuna kıyasla Prunus spinosa grubunda TGF $\beta$ ve kollajen boyanmasında orta şiddetli ve şiddetli boyanmalar (Şekil 3) ve istatistiksel olarak anlamlı $(p<0,05)$ bir artış gözlendi (Şekil 5). Madecassol Grubunda ise şiddetli boyanmalar (Şekil 3) gözlenirken istatistiksel olarak anlamlı $(p<0,05)$ bir artış da gözlendi (Şekil 5).

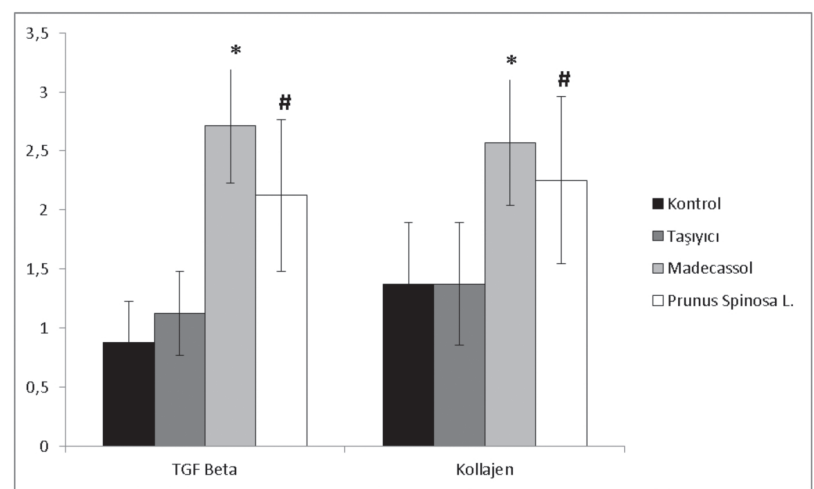

Figür 5. Gruplar arasında immunohistokimyasal (TGF $\beta$ ve kollajen (COL1A1) yara iyileşme skorlaması $(p<0,05)$.

\section{TARTIŞMA}

Yara iyileşmesi, üzerinde sıklıkla çalışılan, iyileşme sürecinin bazı bölümleri detaylı belirtilmesine rağmen, bazı bölümleri hala açıklanmaya muhtaç karmaşık bir biyolojik süreçtir ${ }^{19}$. Hemostaz, inflamasyon, hücre proliferasyonu, ektrasellüler matriks sentezi ve yeniden şekillenme safhalarını içerir ${ }^{20}$. Bu safhaların düzenlenmesi ve kontrolünde farklı faktörler görev alır. Bu faktörler; sitokinler, büyüme faktörleri, proteazlar, eikosanoidler, kininler ve hücresel metabolitlerdir. Bu nedenle onarım sürecindeki olayları tek bir sitokin veya büyüme faktörünün etkisine bağlamak olası değildir ${ }^{21}$. Günümüzde, yaşamda kalma süresinin uzaması, gelişen cerrahi teknikler yara iyileşmesine dair çalışmaların hız kazanmasını sağlamıştır. Geçtiğimiz yüzyılda neredeyse bütün yaralar enfeksiyon gibi komplikasyonlarla ve iz bırakarak iyileşirken, günümüzde yara iyileşmesi ile ilgili yan etkiler azalmıştır. Buna rağmen, çalışmalarda kronik yara olarak adı geçen iyileşmesi zor olan yaralar hala hekimlerin karşısına bir sorun olarak çıkmaktadır ${ }^{22}$. Yara iyileşmesinin normal süreci üzerinde birçok çalışma yapılmasına rağmen, hala tam olarak aydınlatılamayan bazı bölümleri mevcuttur. Dolayısıyla klinik kullanımda amaç, yara iyileşmesinde önemli rol alan faktörleri (inflamatuvar hücreler, trombositler, sitokinler, hücre dışı matriks vb.) etkileyerek, bu dönemlere ait süreleri kısaltmak, ideal olan neovaskülarizasyon ve yara dokusu oluşumunu sağlamaktır ${ }^{23}$. Yara iyileşmesini hızlandırmak ve düzenlemek amacıyla pek çok tıbbi ve geleneksel ilaç kullanımına dair halen çalışmalar yapılmakta ve yeni ürünler araştırılmaktadır. Etki mekanizmaları göz önünde bulundurulduğunda, hücre çoğalmasını, anjiogenezisi ve kollajen sentezini artırıcı ve epitelizasyonu hızlandırıcı pek çok ajan bu amaçla kullanılmakta veya araştırılmaktadır ${ }^{24-28}$.

P. spinosa meyvelerinde, bir flavonoit çeşidi olan ve kardiyovasküler koruyucu, antiinflamatuvar ve antioksidan etkileri olan çeşitli antosiyaninler (siyanidin3-rutinosit, peonidin-3-rutinozit, siyanidin-3-glikozit) bulunmaktadır ${ }^{10}$. P. spinosa meyvelerinin antioksidan etkinlikleri çeşitli çalışmalarda ${ }^{4,7,9,11}$ gösterilmiş olmasına karşın, yara iyileşmesi üzerine topikal etkilerine dair bir bilgiye rastlanmamıştır. Bunu araştırmak amacıyla yaptığımız çalışmamızda, P. spinosa $L$. meyve ekstrelerinin yara iyileşmesini artırıcı bir etki gösterdiğini bulduk. Yara iyileşmesi için önemli olan reepitelizasyon, granülasyon doku kalınlığı ve anjiogenez oranlarında kontrol grubu ile kıyaslandığında, $P$. spinosa grubunda belirgin bir artış gözlemledik.

Yara dokusu iyileşirken düzenli olarak granülasyon dokusu gelişmesi yara iyileşmesinin göstergelerindendir. Granülasyon dokusunda yeni kapiller oluşumlar ile fibroblast hücreleri bulunur. Granülasyon dokusu, cerrahi kesi gibi yaraların iyileşmesinde, enfeksiyona karşı koruyucu bir görevi görür ve yine epitel hücrelerinin göç etmesi için bir zemin oluşturur ${ }^{29}$. Biz de histolojik incelemelerimizde P. spinosanın yara iyileşmesine epitelizasyon ve granülasyon dokusunu artırarak etki ettiğini gözlemledik.

Yara iyileşmesinin kaderinde, reaktif oksijen türevleri (ROT) önemli bir rol oynamaktadır. ROT, metabolik olaylar sırasında bir enzim kompleks mekanizması olan NADPH oksidaz tarafından sentez edilir. Bu ürünlerden hidrojen peroksit $\left(\mathrm{H}_{2} \mathrm{O}_{2}\right)$ bir serbest radi- 
kal gibi hücrelerde önemli hasarlara yol açabilir ${ }^{30,31}$. Serbest radikaller ya da oksidanlar yara bölgesinde doku zedelenmesine neden olarak iyileşme sürecine zarar vermektedir. Bilhassa, hidroksil radikalleri ve $\mathrm{O}^{-}$anyonu, kollajen yapısında bulunan hidroksiprolin ve prolini parçalayarak fibroblastların çoğalma, yapışma ve yaşamda kalma süresinde değişikliğe neden olabilir. Aynı zamanda $\mathrm{H}_{2} \mathrm{O}_{2}$ bir yandan keratinositlerin migrasyonunu engelleyerek, diğer yandan epidermal büyüme faktörü (EGF) sinyal yolunu inhibe ederek fibroblastlarda önemli dejenerasyonlara neden olur ${ }^{31,32}$. Özellikle kronik yaralarda güçlü bir inflamatuvar hücre varlığı ve ROT artışı oksidatif stresin oluştuğunu göstermektedir. Fazla sayıda oluşan ROT hücre hasarına ve ölümüne neden olarak yara iyileşmesini geciktirmektedir. Bu nedenle ROT'un ortadan kaldırılması özellikle kronik yaraların iyileşmesinde önemli bir çözüm olarak karşımıza çıkmaktadır ${ }^{31}$. Serbest radikal süpürücü etkiye sahip olan $\mathrm{P}$. spinosanın antioksidan etkinliği bilinmektedir ${ }^{4,7,9,11}$. Biz de çalışmamızda, önceki çalışmaları destekler nitelikte P. spinosanın yara iyileşmesini olumlu yönde etkilediğini ve iyileşmeyi hızlandırdığını gözlemledik. Kontrol ve taşıyıcı gruba kıyasla $P$. spinosa grubunda yapılan kollajen immünohistokimya boyamalarında anlamlı bir artış gözlemledik ve bu bize P. spinosanın antioksidan etkisi ile kollajen aktivitesini arttırdığını düşündürdü. Yaralarda ROT'in fibroblast çoğalmasını ve göçünü azaltmasına bağlı olarak kollajen sentezini azalttığından söz etmiştik, TGF $\beta$, FGF ve IGF-1 sekresyonlarında da bir azalma meydana gelmektedir. Tüm bu sitokin ve mediatörlerin azalmasına bağlı olarak yara iyileşmesi de gecikmekte, iyileşen yarada deri kalitesi azalmaktadır ${ }^{33}$. TGF- $\beta$, yara iyileşmesindeki önemli mediatörlerden biridir. T lenfositler, endotelyal hücreler, keratinositler, yara dokusu içerisindeki trombositler, makrofajlar, düz kas hücreleri ve fibroblastlar tarafından sekrete edilir. Memelilerde TGF- $\beta 1$, TGF$\beta 2$ ve TGF- $\beta 3$ olmak üzere üç farklı izoformu vardır. TGF- $\beta 1$ ve TGF- $\beta 2$, ekstrasellüler matriks birikimine neden olarak skar dokusu oluşumunu uyarırlar ${ }^{34,35}$. $\mathrm{Bu}$ depolanmayı, ekstrasellüler matriksin üretimini arttırma ve eşzamanlı olarak ekstrasellüler matriksin proteolizini ve yıkımını baskılama yoluyla yaparlar. TGF- $\beta 3$ 'ün ise diğer iki izoformun aksine skar dokusu oluşumunu azaltıcı yönde etkisinin olduğunu gösteren çalışmalar vardır ${ }^{34-36}$. Biz de çalışmamızda, kontrol ve taşıyıcı gruba kıyasla $P$. spinosa grubunda yapılan TGF $\beta$ immünohistokimya boyamalarında anlamlı bir artış gözlemledik ve bu bize P. spinosanın antioksidan etkisi ile TGF $\beta$ aktivasyonunu artırdığını düşündürdü. Sonuçlarımız, P. spinosanın bağ doku formasyonunu artırarak ve inflamatuvar hücreleri inhibe ederek yara iyileşmesini hızlandırdığını düşündürdü, daha kesin sonuçlara ulaşabilmek için farklı immünohistokimyasal boyamaların (FGF, VGEF, PDGF vb.) yapılması ve daha fazla denekle çalışılmasının uygun olduğunu düşünmekteyiz. Bu ve benzeri çalışmalar, P. spinosanın birçok sisteme olan yararlı etkileri yanı sıra yara iyileşmesini artırdığını gösteren etkisiyle beraber daha çok araştırılması, tanınması ve ileri deneysel çaIışmalar yapılması için basamak olabileceği düşünülmektedir. Yara iyileşme süreci güvenli preparatlarla desteklenirse kronik yaralar sorun olmaktan çıkabilir. Belki de yara iyileşmesi tedavilerinde bu moleküllerin rutin kullanımına geçilebilir.

\section{KAYNAKLAR}

1. Güner A. Türkiye Bitkileri Listesi (Damarlı Bitkiler). 1. Baskı. İstanbul, Türkiye: Nezahat Gökyiğit Botanik Bahçesi Yayınları, Flora Dizisi 1. 2012.

2. Halasz J, Makovics-Zsohar N, Szoke F, et al. Simple Sequence Repeat and S-locus Genotyping to Explore Genetic Variability in Polyploid Prunus spinosa and P. insititia. Biochem Genet 2017;55:22-33.

https://doi.org/10.1007/s10528-016-9768-3

3. Baytop T. Türkçe Bitki Adları Sözlüğü, TDK yayınları 1997; 578. Ankara.

4. Başkaya Sezer D, Tokatlı Erdoğan K, Demiröven A. Çakal Eriği ve Yonuz Eriği Marmelatları. J Agric Fac Gaziosmanpasa Univ 2016;33:125-131. https://doi.org/10.13002/jafag899

5. Baytop T. Türkiye'de bitkiler ile tedavi. 2. Baskı. Nobel Tıp Kitabevleri, İstanbul, 1999; 204-205.

6. Türkan Ş, Malyer H, Özaydın S, Tümen G. Ordu İli ve Çevresinde Yetişen Bazı Bitkilerin Etnobotanik Özellikleri. SDÜ Fen Bil Enst Der 2006; 162-166.

7. Barros L, Carvalho AM, Morais JS, Ferreira ICFR. Strawberrytree, blackthorn and rose fruits: Detailed characterisation in nutrients and phytochemicals with antioxidant properties. Food Chem 2010;120:247-254. https://doi.org/10.1016/j.foodchem.2009.10.016

8. Gruenwald J, Brendler T, Jaenicke C. PDR for Herbal Medicine, Third Edition, 738.

9. Ruiz-Rodriguez BM, Ancos B, Sanchez-Moreno C, et al. Wild blackthorn (Prunus spinosa L.) and hawthorn (Crataegus monogyna Jacq.) fruits as valuable sources of antioxidants. Fruits 2013;69(1):61-73. 
https://doi.org/10.1051/fruits/2013102

10. Fraternale D, Giamperi L, Bucchini A, et al. Prunus spinosa fresh fruit juice: antioxidant activity in cell-free and cellular systems. Nat Prod Commun 2009;4:1665-70.

11. Egea I, Sánchez-Bel P, Romojaro F, Pretel MT. Six edible wild fruits as potential antioxidant additives or nutritional supplements. Plant Foods Hum Nutr 2010;65:121-129.

https://doi.org/10.1007/s11130-010-0159-3

12. Cavalcanti JM, Leal-Cardoso JH, Diniz LR, et al. The essential oil of Croton zehntneri and trans-anethole improves cutaneous wound healing. J Ethnopharmacol 2012;430 144:240247. https://doi.org/10.1016/j.jep.2012.08.030

13. de Oliveira ML, Bezerra BM, Leite LO, et al. Topical continuous use of Lippia sidoides Cham essential oil induces cutaneous inflammatory response, but does not delay wound healing process. J Ethnopharmacol 2014;153:283-289. https://doi.org/10.1016/j.jep.2014.02.030

14. Karodi R, Jadhav M, Rub R, Bafna A. Evaluation of the wound healing activity of a extract of Rubia cordifolia L. (Indianmadder) in mice. Int J Appl Res Nat Prod 2009;2:12.

15. Ximenes RM, de Morais Nogueira L, Cassundé NM, et al. Antinociceptive and wound healing activities of Croton adamantinus Müll. Arg. essential oil. J Nat Med 2013;67:758-764. https://doi.org/10.1007/s11418-012-0740-1

16. Gunal MY, Heper A, Zaloglu N. The Effect of Topical Carvacrol Application on wound healing process in male rats. Phcog $J$ 2014;6(3):10-14. https://doi.org/10.5530/pj.2014.3.2

17. Galeano M, Altavilla D, Bitto A, et al. Recombinant human erythropoietin improves angiogenesis and wound healing in experimental burn wounds. Crit Care Med 2006;34:11391146. https://doi.org/10.1097/01.CCM.0000206468.18653.EC

18. Tuzun F, Gencpınar P, Ozbal S, et al. Neuroprotective effect of neotrofin in a neonatal rat model of periventricular leukomalacia. Neurosci Lett 2012;520(1):6-10. https://doi.org/10.1016/j.neulet.2012.04.076

19. Arab A, Orakcı V, Erbilen M, et al. Yara iyileşmesi. Journal of Turgut Özal Medical Centre 1994;1(2):160-66.

20. Christine L, Theoret DM. Diplomate ACVS; update on wound repair. Clin Tech Equine Pract 2004;3:110-112. https://doi.org/10.1053/j.ctep.2004.08.009

21. Henry G, Garner WL. Inflammatory mediators in wound healing. Surg Clin N Am 2003;83:483-507. https://doi.org/10.1016/S0039-6109(02)00200-1

22. Mustoe TA, O'Shaughnessy K, Loeters O. Chronic wound pathogenesis and current treatment strategies: a unifying hypothesis. Plast Reconstr Surg 2006;117:35-41. https://doi.org/10.1097/01.prs.0000225431.63010.1b

23. Gürbüz O. Yara iyileşmesinde yeni ufuklar. Erdem C. Edit. Tüm yönleri ile yara iyileşmesi, Ankara 1996; 145-8.

24. Aydın OE, Tan O, Çinal $\mathrm{H}$ et al. Experimental wound models. Turkiye Klinikleri J Plast Surg-Special Topics 2015;4(1):5-11.

25. Kawanabe T, Kawakami T, Yatomi Y, et al. Sphingosine 1-phosphate accelerates wound healing in diabetic mice. $J$ Dermatol Sci 2007;48(1):53-60. https://doi.org/10.1016/j.jdermsci.2007.06.002

26. Asai J, Takenaka H, Hirakawa S, et al. Topical Simvastatin Accelerates Wound Healing in Diabetes by Enhancing Angiogenesis and Lymphangiogenesis. Am J Pathol 2012;181:221724. https://doi.org/10.1016/j.ajpath.2012.08.023

27. Somboonwong J, Kankaisre $\mathrm{M}$, Tantisira $\mathrm{B}$ and Tantisira $\mathrm{MH}$. Wound healing activities of different extracts of Centella asiatica in incision and burn wound models: an experimental animal study. BMC Complementary and Alternative Medicine 2012;12:103. https://doi.org/10.1186/1472-6882-12-103

28. Özkorkmaz EG, Özay Y. Yara İyileşmesi ve Yara İyileşmesinde Kullanılan Bazı Bitkiler. Türk Bilimsel Derlemeler Dergisi 2009;2:63-67.

29. Stashak TS. Principle of wound healing. In: Equine Wound Management 1991;1:1-15.

30. Hensley K, Robinson KA, Gabbita SP, et al. Reactive oxygen species, cell signaling, and cell injury. Free Radic Biol Med 2000;28:1456-62. https://doi.org/10.1016/S0891-5849(00)00252-5

31. Aksoy H, Özakpınar Bingöl Ö. Yara iyileşmesi ve oksidatif stres. Marmara Pharmaceutical Journal 2014;18:153-158. https://doi.org/10.12991/mpj.2014187243

32. Yager DR, Kulina RA, Gilman LA. Wound fluids: a window into the wound environment? Int J Low Extrem Wounds 2007;6:262-72. https://doi.org/10.1177/1534734607307035

33. Won-Serk K, Byung-Soon P, So-Hyun P, et al. Antiwrinckle effect of adipose-derived stem cell: activation of dermal fibroblast by secretory factors. Journal of Dermatology Science 2009;53:96-102. https://doi.org/10.1016/j.jdermsci.2008.08.007

34. Shah $M$, Foreman DM, and Ferguson MW. Neutralising antibody to TGF- $\beta 1,2$ reduces cutaneous scarring in adult rodents. Journal of Cell Science 1994;107:1137-1157.

35. Shah M, Foreman DM, and Ferguson MWJ. Neutralisation of TGF- $\beta 1$ and TGF- $\beta 2$ or exogenous addition of TGF- $\beta 3$ to $\mathrm{cu}-$ taneous rat wounds reduces scarring. Journal of Cell Science 1995;108: 985-1002.

36. Li W, Huang EY, Dudas M, Kaartinen V, et al. Transforming growth factor- $\beta 3$ affects plasminogen activator inhibitor-1 expression in fetal mice and modulates fibroblastmediated collagen gel contraction. Wound Rep Reg 2006;14:516-525. https://doi.org/10.1111/j.1743-6109.2006.00158.x 